\title{
Gram Negative Bacteria Measurement
}

National Cancer Institute

\section{Source}

National Cancer Institute. Gram Negative Bacteria Measurement. NCI Thesaurus. Code C154812.

The determination of the gram-negative bacteria present in a sample. 